\title{
Ultrastructure of the apical glandular region of the scolex of Proteocephalus torulosus (Cestoda: Proteocephalidae)
}

\author{
Zdeňka Žd’árská, Tomáš Scholz and Jana Nebesářová
}

Institute of Parasitology, Academy of Sciences of the Czech Republic, Branišovská 31, 37005 České Budějovice, Czech Republic

Key words: Cestoda, Proteocephalus torulosus, apical glandular region, transmission electron microscopy

\begin{abstract}
In the apical glandular region of the adult Proteocephalus torulosus (Batsch, 1786), two types of eccrine gland cells are present. The first type of unicellular gland produces large electron-dense granules of various sizes. The second type contains small electron-dense granules. Most cells form glands with large granules; glands with small granules are infrequent. The secretion of both types of gland cells is concentrated in the apical parts of the cyton and in the ducts opening to the exterior. On the scolex of $P$. torulosus, there are regional structural differences of the microthrix border. The apical glandular region bears filamentous microtriches only. On the remaining frontal part, surrounding the glandular region, there are blade-like and filamentous microtriches. The lateral parts of the scolex and suckers bear blade-like microtriches. Possible functions of both types of gland cells and different parts of the scolex microthrix border are discussed. The unique structure of the frontal part of the scolex of $P$. torulosus and its differences from Proteocephalus macrocephalus, P. longicollis and P. percae correlate well with the putative basal phylogenetic position of $P$. torulosus among European species of Proteocephalus.
\end{abstract}

The information about the ultrastructure of the tegument, including gland cells, may be useful in the systematics of proteocephalidean and other fish cestodes (Žd'árská and Nebesářová, 1997, 1999a, b, 2003, Scholz et al. 1998, Scholz and Hanzelová 1998, Scholz 1999, Škeříková et al. 2001). Scolex gland cells are characteristic of cestodes and occur in all stages of the life cycle (McCullough and Fairweather 1989). Hypotheses concerning their role in migration, penetration and production of adhesive material have been discussed by Gustafsson and Vaihela (1981), Kuperman and Davydov (1982) and Žd'árská and Nebesáŕová (1997).

The glands and microthrix border of the scolex of Proteocephalus torulosus (Batsch, 1786) (Cestoda: Proteocephalidae) have not been studied using transmission electron microscopy. This species differs from taxa of Proteocephalus from European freshwater fish by possessing a large, club-shaped scolex devoid of an apical sucker (Scholz and Hanzelová 1998, Scholz et al. 1998). Earlier, two types of gland cells have been detected in P. macrocephalus by Žd'árská and Nebesářová $(1995,1999 \mathrm{a}, \mathrm{b})$, in P. osculatus by Stoitsova et al. (1995) and in P. longicollis by Bruňanská et al. (2000). Four mechanisms of secretory material release have been described in cestodes - eccrine, apocrine, microapocrine, and holocrine (Kuperman and Davydov 1982).

\section{MATERIALS AND METHODS}

Adult specimens of Proteocephalus torulosus (Batsch, 1786) recovered from the intestine of chub, Leuciscus cephalus (L.), from the River Rokytná, Czech Republic, were fixed with $3 \%$ glutaraldehyde in $0.1 \mathrm{M}$ sodium cacodylate buffer (pH 7.2) for $2 \mathrm{~h}$ at $4^{\circ} \mathrm{C}$, postfixed for $2 \mathrm{~h}$ at $4^{\circ} \mathrm{C}$ in $2 \%$ osmium tetroxide, dehydrated through an acetone series and embedded in Durcupan. Series of ultrathin sections were cut with a Reichert Jung Ultracut E ultramicrotome, double stained with uranyl acetate and lead citrate, and viewed in a JEOL 1010 transmission electron microscope operated at $80 \mathrm{kV}$. Semithin sections were stained with toluidine blue.

\section{RESULTS}

\section{Gland cells}

The apical glandular region is infolded and forms deep tegumental invaginations (Figs. 1, 6, 7, 11) into which ducts of two types of eccrine gland cells open (Figs. 6, 7, 9, 12). The main part of cells forms glands with large electron-dense granules of various size (G1 maximum 1,200 $\times 800 \mathrm{~nm}$ ). Glands with small, more or less oval, electron-dense granules $(\mathrm{G} 2-500 \times 250 \mathrm{~nm})$ are solitary distributed (Figs. 1, 6, 7, 12). The gland ducts (Figs. 7, 9, 12) penetrate the basal lamina and basal tegument plasma membrane where the terminal part of the duct is reinforced by a dense collar. Opposite to the collar, a septate junction fixes the duct to the apical tegument plasma membrane. The ducts are reinforced by peripheral microtubules (Figs. 5, 6, 8-11). The perinuclear parts of gland cells, localised deep in the parenchyma, contain rough endoplasmic reticulum, Golgi complexes and some mitochondria.

\section{Microtriches}

The tegument of the apical glandular region differs from the tegument covering the remaining parts of the scolex, i.e. the frontal part around the apical glandular 


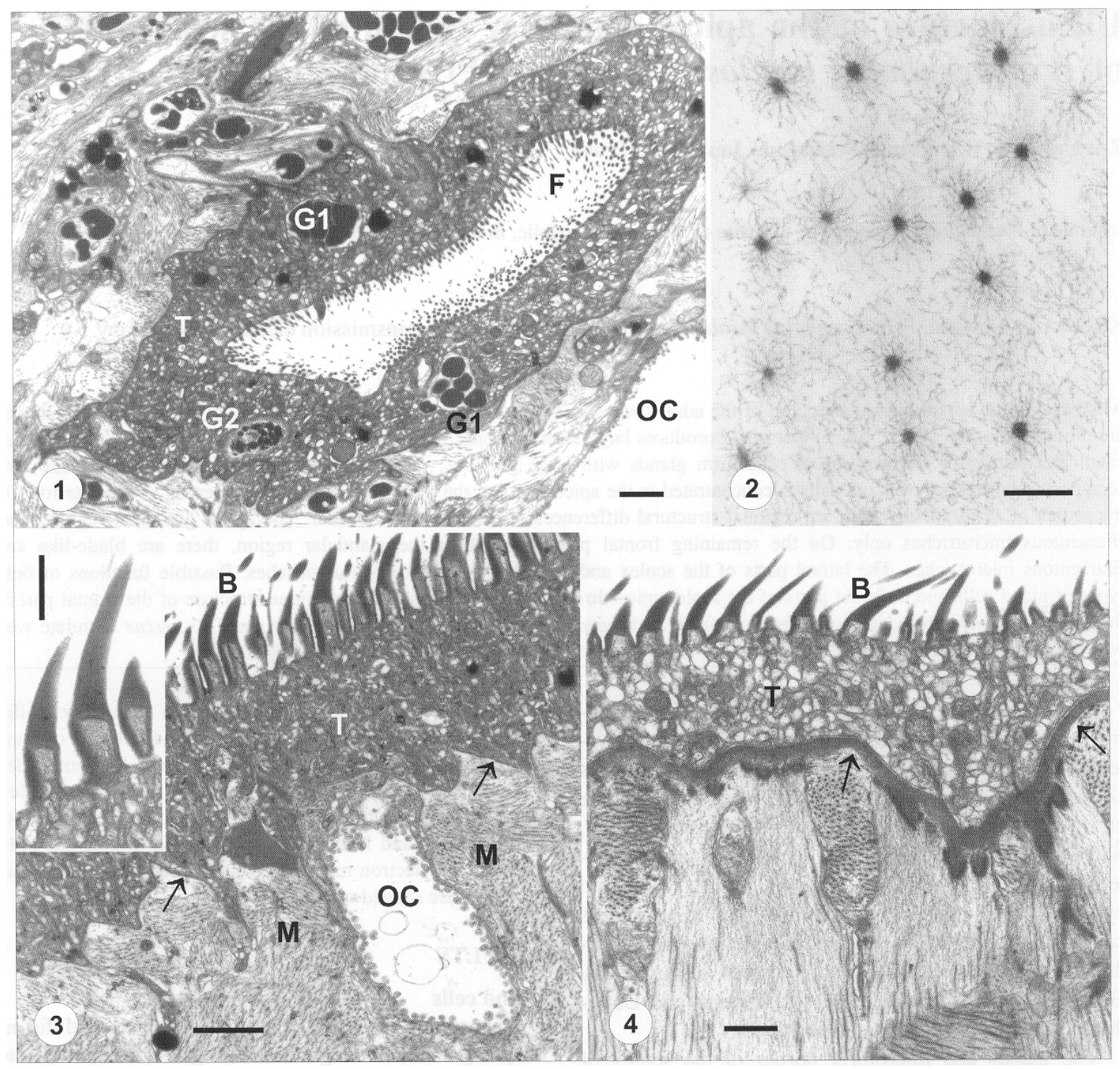

Figs. 1-4. Microthrix border of the apical glandular region, the lateral part of the scolex and suckers of Proteocephalus torulosus, transmission electron micrographs. Fig. 1. Cross-section of an infolding of the apical glandular region. Note the filamentous microtriches (F), ducts with large (G1) and small (G2) electron-dense granules and an osmoregulatory canal (OC) close to the tegument (T). Fig. 2. Cross-section of the apical parts of the filamentous microtriches of the apical glandular region. Note the radial orientation of the glycocalyx filaments. Fig. 3. The tegument $(\mathrm{T})$ of the lateral part of the scolex with blade-like microtriches (B). The tegument basal lamina (arrows) is in close contact with osmoregulatory canal (OC) penetrating through the longitudinal and circular muscle layers (M). Inset: detail of blade-like microtriches. Fig. 4. Sucker tegument (T) with blade-like microtriches (B). Arrows - basal lamina. Scale bars: Figs. 1, $3=1 \mu \mathrm{m}$; Fig. $2=200 \mathrm{~nm}$; Figs. 3 (inset), $4=500 \mathrm{~nm}$.

region and the part between and inside the suckers. The tegument of the apical glandular region bears filamentous microtriches only (Figs. 1, 2, 5-7, 9, 11, 12). The base of the filamentous microtriches is slim and the shaft is two times longer than the base. In cross-section, both base and shaft have a round form (Figs. 1, 2, 6). The apical plasma membrane, covering the microtriches, bears a glycocalyx with radial orientation of filaments (Fig. 2).
The tegument of the frontal part of the scolex bears two distinct types of microtriches - filamentous and blade-like. This part represents a transitional zone between the frontal and lateral parts of the scolex. The number of blade-like microtriches increases in the lateral direction and that of filamentous decreases. On the lateral part of the scolex (i.e. between suckers), only blade-like microtriches are present. These microtriches consist of a long narrow basal part and a long shaft (Fig. 


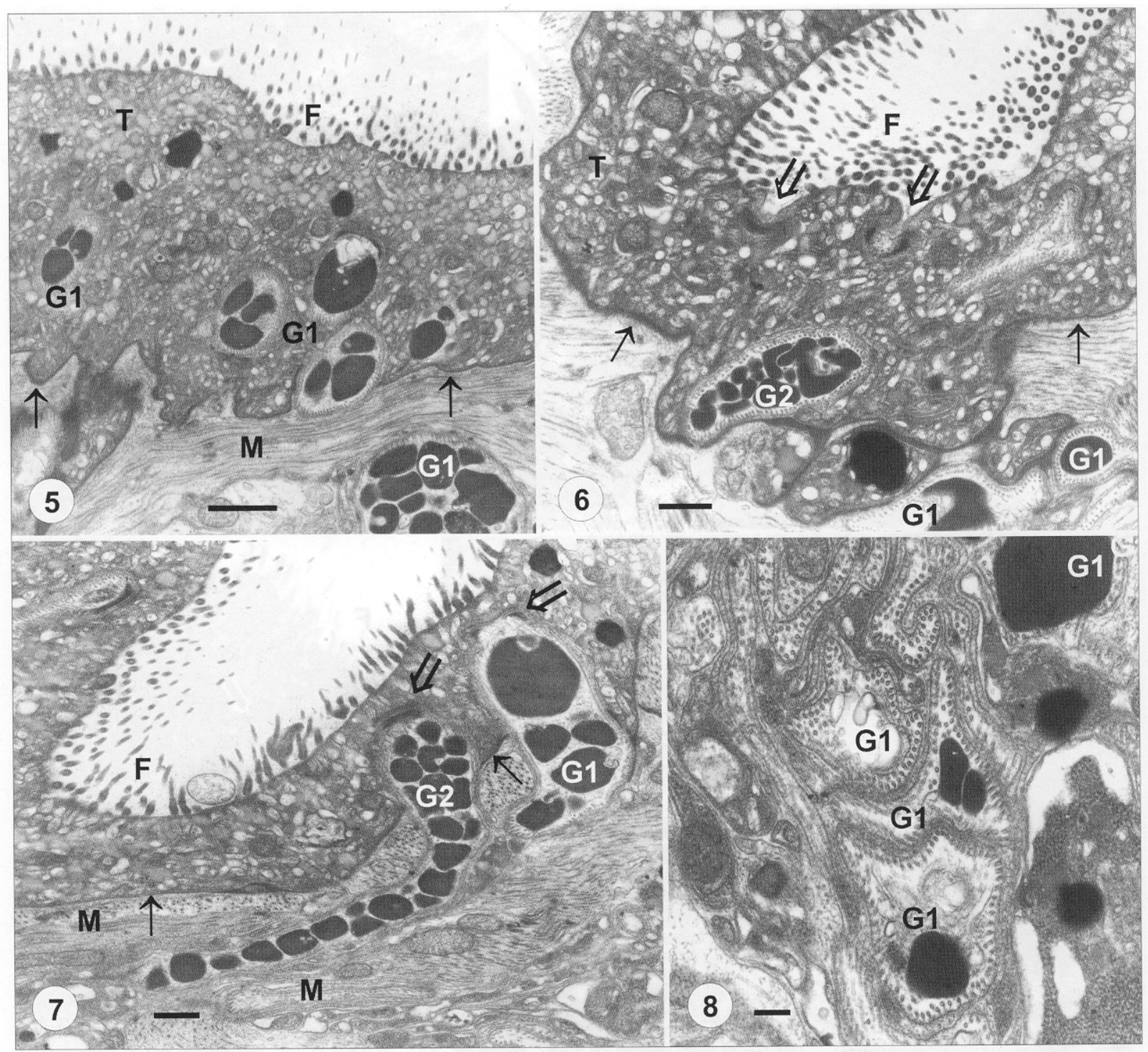

Figs. 5-8. Gland cell ducts of the apical glandular region of the scolex of Proteocephalus torulosus, transmission electron micrographs. Fig. 5. Accumulation of gland cell ducts with large electron-dense granules (G1) in the tegument (T). Arrows basal lamina, M - muscle layer, F - filamentous microtriches. Fig. 6. Invaginated tegument $(\mathrm{T})$ with two gland duct openings (double arrows) encircled by a septate junction. Note one duct of gland cell with small electron-dense granules (G2) in the tegument and two ducts of gland cells with large electron-dense granules (G1) below the basal lamina (arrow). F - filamentous microtriches. Fig. 7. Two ducts of gland cells (G1 and G2) penetrate basal lamina (arrows) and tegument of the infolded part of the apical glandular region. F - filamentous microtriches, double arrows - septate junctions, $\mathrm{M}$ - muscle layer. Fig. 8. Accumulation of gland ducts (G1) below the muscle layer. Note peripheral microtubules reinforcing ducts. Scale bars: Fig. $5=1 \mu \mathrm{m}$; Figs. $6,7=500 \mathrm{~nm}$; Fig. $8=200 \mathrm{~nm}$.

3 and inset). The tegument of the suckers bears bladelike microtriches, but the microthrix basal part is wide and short (Fig. 4).

\section{DISCUSSION}

In adult Proteocephalus torulosus the formation designated as apical organ (Freze 1965, Scholz 1989) does not form an organ during ontogeny. Unlike most species of Proteocephalus from European fish, P. torulosus does not possess an apical sucker. The apical part of the scolex contains the parenchyma with high accumulation of gland cells (Scholz et al. 1998). They are not separated from the scolex parenchyma by a fibrose sheath as are the suckers, including the apical sucker. The apical glandular region of $P$. torulosus probably corresponds to gland cells concentrated around the apical sucker in Proteocephalus species where the apical sucker is more or less developed (Scholz at al. 1998). 


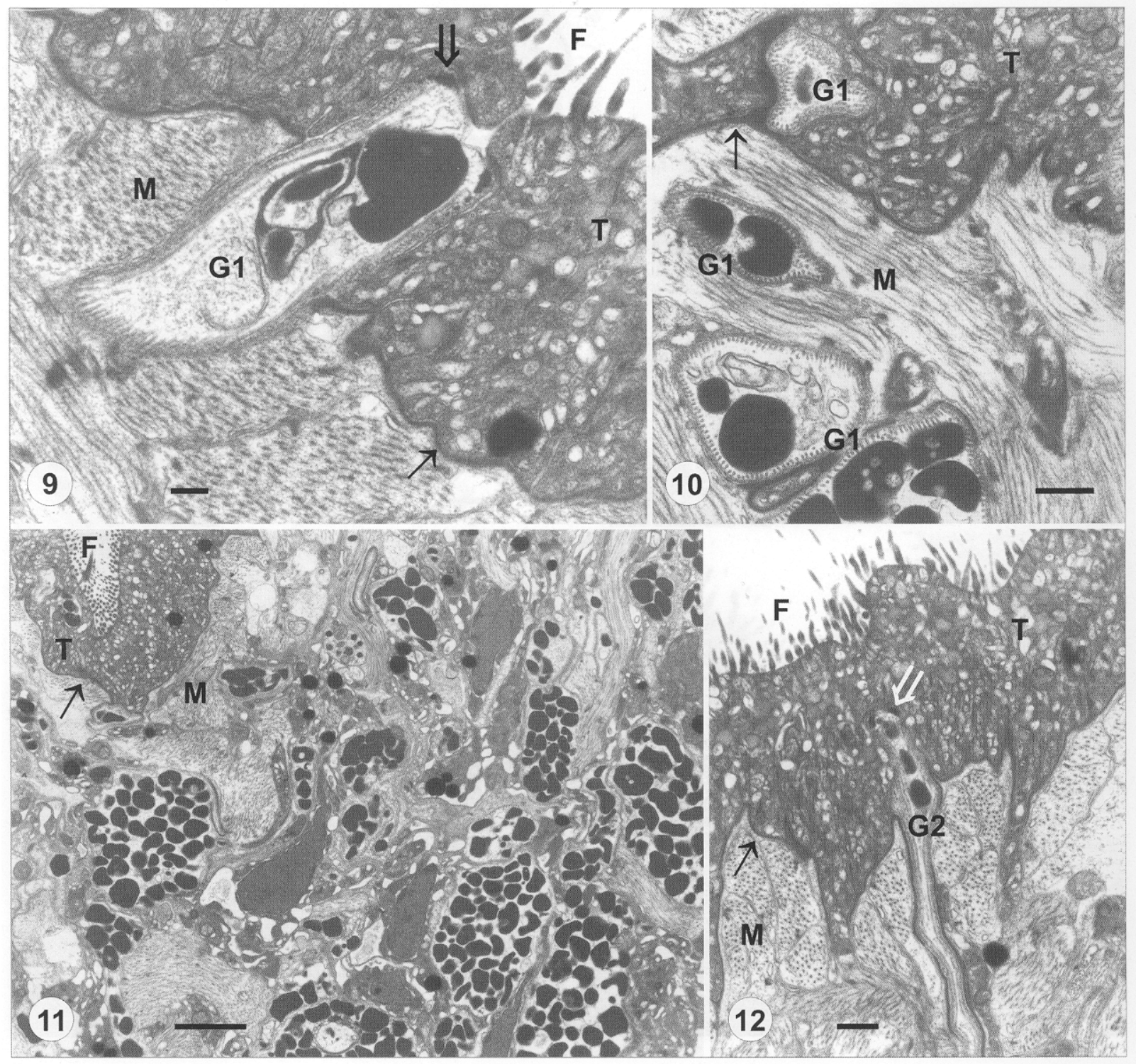

Figs. 9-12. Gland cell bodies and ducts of the apical glandular region of Proteocephalus torulosus, transmission electron micrographs. Fig. 9. Detail of a duct of a G1 gland cell penetrating the muscle layer (M), basal lamina (arrow) and tegument (T). The duct is reinforced by a dense collar (double arrow). Inside the duct there are some membranous formations and a large dense granulum. F - filamentous microtriches. Fig. 10. Tangential sections through ducts (G1) in the tegument (T) and among muscle fibres (M). Arrow - basal lamina. Fig. 11. Section through a deeper part of the scolex parenchyma at the level of the apical parts of G1 gland cell bodies. T - tegument invagination, $\mathrm{F}$ - filamentous microtriches, arrow - basal lamina, $\mathrm{M}$ - muscle layer. Fig. 12. Detail of the duct of a G2 gland cell penetrating the muscle layers (M), basal lamina (arrow) and tegument (T) apically reinforced by a dense collar (double arrow). F - filamentous microtriches. Scale bars: Figs. 9, $11=500 \mathrm{~nm}$; Fig. $10=200 \mathrm{~nm}$; Fig. $12=2 \mu \mathrm{m}$

The gland cells localised around the apical sucker (i.e. on the frontal part of the scolex) were studied in detail in P. macrocephalus (Scholz et al. 1998, Žd'árská and Nebesáŕová 1999a), P. percae (Andersen 1979, Kuperman 1988, Scholz et al. 1998), P. longicollis (Bruňanská et al. 2000), P. exiguus (Kuperman 1988, Scholz et al. 1998) $(=P$. longicollis according to Scholz and Hanzelová 1998) and P. osculatus (Stoitsova et al.
1995). The gland cells of the frontal part of the scolex of Proteocephalus species without an apical sucker were studied in P. gobiorum (Kuperman 1988), P. ambloplitis (Coggins 1980), P. sagittus and P. torulosus (Scholz et al. 1998). There are reports of the ultrastructure and functions of gland cells in the scolices of other adult cestodes (McCullough and Fairweather 1989, Stoitsova et al. 1997, Whittington and Cribb 2001). 
The secretory product of the scolex eccrine glands of $P$. torulosus differs from that of $P$. macrocephalus studied earlier by Žd'árská and Nebesářová (1999a). In $P$. torulosus, both types contain electron-dense granules, whereas only one type of eccrine gland produces electron-dense granules and the second one electronlucid granules in P. macrocephalus. The glands with electron-dense granules may function in penetration into the host intestinal epithelium. McCullough and Fairweather (1989) suggested for them proteolytic, adhesive and protective functions. The functions of the glands with large electron-dense granules in $P$. torulosus and large electron-lucid granules in $P$. macrocephalus, are not known. In comparison with the ultrastructure of glands of other Proteocephalus species, large electronlucid granules were not observed in adults, but only in larval stages of $P$. longicollis (Bruňanská et al. 2000).

In microthrix border of the scolex forepart of $P$. torulosus, only two types of microtriches, filamentous and blade-like, were detected. On the apical glandular region, there are only filamentous microtriches. On the frontal part, surrounding the glandular region, the filamentous microtriches decrease in size whereas the blade-like ones increase. The lateral part of the scolex and the suckers are covered with only blade-like microtriches. The filamentous microtriches may function in resorption, the blade-like ones in fixation. Lumsden (1975) and MacKinnon and Burt (1983) have suggested a nutritional function for filamentous microtriches. Rothman (1963) and Hayunga (1991) proposed an anchoring function of the caps and a nutritional function for the bases. Palm et al. (2000), on the other hand, considered the possibility of multiple functions. In P. torulosus, the resorptive part of the tegument is lower than that of $P$. macrocephalus, where filamentous microtriches are distributed on the whole anterior part of the scolex and suckers (Žd'árská and Nebesářová 1999a).

The present study has revealed marked differences in the fine structure of gland cells and microtriches on the apical part of the scolex between $P$. torulosus and $P$. macrocephalus, as well as from other species of Proteocephalus from European freshwater fish (Andersen 1979, Kuperman 1988, Stoitsova et al. 1995, Scholz et al. 1998, Bruňanská et al. 2000).

The unique structure of the frontal part of the scolex of $P$. torulosus and its differences from $P$. macrocephalus, P. longicollis (syn. P. exiguus) and P. percae correlate well with the putative basal phylogenetic position of $P$. torulosus among European species of Proteocephalus. Phylogenetic analyses based on molecular (16S, 18S and 28S rDNA) and morphological data (Zehnder and Mariaux 1999, Škeříková et al. 2001, de Chambrier et al. 2004) placed P. torulosus as a basal group in the clade containing all but one species of Proteocephalus. All these taxa possess a vestigial apical sucker (P. ambiguus, $P$. cernuae, $P$. filicollis, $P$. longicollis, P. macrocephalus, $P$. percae, $P$. tetrastomus, $P$. thymalli). The only Palaearctic species of Proteocephalus that has a well-developed, functional apical sucker with a deep cavity is $P$. osculatus, a specific parasite of wels (Silurus glanis) (see Scholz et al. 1998, Scholz and Hanzelová 1998). This species appeared in all phylogenetic analyses as the most primitive representative of this group of Proteocephalus cestodes (Zehnder and Mariaux 1999, Škeříková et al. 2001). Based on its phylogenetic position and morphology, de Chambrier et al. (2004) have proposed a new genus, Glanitaenia, to accommodate P. osculatus.

Acknowledgements. We are grateful for the help given by Mrs. M. Borovková in collecting the hosts. We also appreciate the technical assistance of Mr. A. Polák and Mrs. P. Masařová. This study was supported by the Grant Agency of the Czech Republic (project no. 524/04/0342) and research projects of the Institute of Parasitology ASCR (Z 6022909 and K 600 5114).

\section{REFERENCES}

ANDERSEN K. 1979: Variation in scolex morphology within and between some species of the genus Proteocephalus Weinland (Cestoda, Proteocephala) with references to strobilar morphology. Zool. Scr. 8: 241-248.

BRUŇANSKÁ M., FAGERHOLM H.-P., GUSTAFSSON M.K.S. 2000: Ultrastructure studies of Proteocephalus longicollis (Cestoda, Proteocephalidea): transmission electron microscopy of scolex glands. Parasitol. Res. 86: 717723.

COGGINS J.R. 1980: Tegument and apical end organ fine structure in the metacestode and adult Proteocephalus ambloplitis. Int. J. Parasitol. 10: 409-418.

DAVYDOV V.G., PODDUBNAYA L.G. 1988: Functional morphology of the frontal and uterine glands in representative cestodes of the order Caryophyllidea. Parazitologiya 22: 449-457. (In Russian.) de CHAMBRIER A., ZEHNDER M., VAUCHER C., MARIAUX J. 2004: The evolution of the Proteocephalidea (Platyhelminthes, Eucestodes) based on an enlarged molecular phylogeny, with comments on their uterine development. Syst. Parasitol. 57: 159-171.

FREZE V.I. 1965: [Proteocephalids - Tapeworm Helminths of Fish, Amphibians and Reptiles. Essentials of Cestodology.] Vol. V. Publ. House Nauka, Moscow, 540 pp. (In Russian.)

GUSTAFSSON M.K.S., VAIHELA B. 1981: Two types of frontal glands in Diphyllobothrium dendriticum (Cestoda, Pseudophyllidea) and their fate during the maturation of the worm. Z. Parasitenkd. 66: 145-154.

HAYUNGA E.G. 1991: Morphological adaptations of intestinal helminths. J. Parasitol. 77: 865-873. 
KUPERMAN B.I. 1988: Functional Morphology of Lower Cestodes. Publ. House Nauka, Leningrad, 167 pp. (In Russian.)

KUPERMAN B.I., DAVYDOV V.G. 1982: The fine structure of frontal glands in adult cestodes. Int. J. Parasitol. 12: 285-293.

LUMSDEN R.D. 1975: Parasitological review: surface ultrastructure and cytochemistry of parasitic helminths. Exp. Parasitol. 37: 267-339.

Mac KINNON B.M., BURT M.D.B. 1983: Polymorphism of microtriches in the cysticercoid of Ophryocotyle insignis Lonnberg, 1890 from limpet Patella vulgata. Can. J. Zool. 61: 1062-1070.

McCULLOUGH J.S., FAIRWEATHER I. 1989: The fine structure and possible function of scolex gland cells in Trilocularia acanthiaevulgaris (Cestoda, Tetraphyllidea). Parasitol. Res. 75: 575-582.

PALM H.W., MUNDT U., OVERSTREET R. 2000: Sensory receptors and surface ultrastructure of trypanorhynch cestodes. Parasitol. Res. 86: 821-833.

ROTHMAN A. 1963: Electron microscopy studies of tapeworms: the surface structures of Hymenolepis diminuta (Rudolphi, 1819) Blanchard, 1891. Trans. Am. Microsc. Soc. 82: 22-30.

SCHOLZ T. 1989: Amphilinida and Cestoda, parasites of fish in Czechoslovakia. Acta Sci. Nat. Brno 23, No. 4, 56 pp.

SCHOLZ T. 1999: Life cycles of species of Proteocephalus, parasites of fishes in the Palearctic Region: a review. J. Helminthol. 73: 1-19.

SCHOLZ T., DRÁBEK R., HANZELOVÁ V. 1998: Scolex morphology of Proteocephalus tapeworms (Cestoda, Proteocephalidae), parasites of freshwater fish in the Palearctic Region. Folia Parasitol. 45: 27-43.

SCHOLZ T., HANZELOVÁ V. 1998: Tapeworms of the genus Proteocephalus Weinland, 1958 (Cestoda: Proteocephalidae), parasites of fishes in Europe. Studie AV ČR, 2/98, Academia, Prague, $218 \mathrm{pp}$.

SCHOLZ T., ŽĎÁRSKÁ Z., de CHAMBRIER A., DRÁBEK R. 1998: Scolex morphology of the cestode Silurotaenia siluri (Batsch, 1786) (Proteocephalidae: Gangesiinae), a parasite of European wels (Silurus glanis). Parasitol. Res. 85: $1-6$.

ŠKEŘÍKOVÁ A., HYPŠA V., SCHOLZ T. 2001: Phylogenetic analysis of European species of Proteocephalus (Cestoda: Proteocephalidae): compatibility of molecular and morphological data, and parasite-host coevolution. Int. J. Parasitol. 31: 1121-1128.

STOITSOVA S.R., GEORGIEV B.B., DACHEVA R.B., VINAROVA M.I. 1995: Ultrastructural and cytochemical demonstration of two types of scolex glands in Proteocephalus osculatus (Cestoda: Proteocephalidae). C. R. Acad. Bulg. Sci. 48: 97-99.

STOITSOVA S.R., GEORGIEV B.B., DACHEVA R.B., VINAROVA M.I. 1997: Scolex glands associated with the rostella in three species of the Dilepididae (Cestoda: Cyclophyllidea). Acta Zool. 78: 187-193.

WHITTINGTON I.D., CRIBB B.W. 2001: Adhesive secretions in the Platyhelminthes. Adv. Parasitol. 48: 102-207.

ŽĎÁRSKÁ Z., NEBESÁŘOVÁ J. 1997: Ultrastructure of three types of scolex gland cells of Bothriocephalus claviceps (Cestoda: Pseudophyllidea). Folia Parasitol. 44: 139-146.

ŽĎÁRSKÁ Z., NEBESÁŘOVÁ J. 1999a: Distribution and ultrastructure of two types of scolex gland cells in adult Proteocephalus macrocephalus (Cestoda: Proteocephalidea). Parasite 6: 49-56.

ŽĎÁRSKÁ Z., NEBESÁŘOVÁ J. 1999b: Regional ultrastructural differences of the scolex and neck tegument of Proteocephalus macrocephalus (Eucestoda: Proteocephalidea). Folia Parasitol. 46: 279-283.

ŽĎÁRSKÁ Z., NEBESÁŘOVÁ J. 2003: Ultrastructure of the early rostellum of Silurotaenia siluri (Batsch, 1786) (Cestoda: Proteocephalidea). Parasitol. Res. 89: 495-500.

ZEHNDER M.P., MARIAUX J. 1999: Molecular systematic analysis of the order Proteocephalidea (Eucestoda) based on mitochondrial and nuclear rDNA sequences. Int. J. Parasitol. 29: 1841-1852.

Accepted 18 July 2004 